Journal of Animal and Veterinary Advances 10 (5): 606-609, 2011

ISSN: $1680-5593$

(C) Medwell Journals, 2011

\title{
Fattening Performance and Dressing Percentage of Holstein Crossbred Bulls at Different Initial Weights in Southeastern Anatolia Region
}

\author{
${ }^{1}$ Mugdat Yerturk, ${ }^{2}$ Oktay Kaplan and ${ }^{2}$ Mehmet Avci \\ ${ }^{1}$ Department of Animal Sciences, ${ }^{2}$ Department of Animal Nutrition and Nutritional Diseases, \\ Faculty of Veterinary Medicine, Harran University, Sanliurfa, Turkey
}

\begin{abstract}
This study was carried out to investigate fattening performance and dressing percentage of Holstein crossbred young bulls at different initial live weights in a private farm in Southeastern Anatolia region. The young bulls in the study were divided into three groups according to their initial live weights $(123.70,168.56$ and $216.58 \mathrm{~kg}$ ). Fattening periods, finishing weights, average daily weight gain and feed conversion rate for group I-III were $183.11,176.72$ and 186.25 day, $319.47,360.68$ and $419.04 \mathrm{~kg}, 1061,1086$ and $1101 \mathrm{~g} ; 7.09,8.08$ and $8.73 \mathrm{~kg}$, respectively. Average daily live weights gain of the groups for whole fattening periods were not significant but average fed conversions ratio of the group were found statistically significant $(\mathrm{p}<0.05)$. Dressings percentage of 6 animals from each group at the end of fattening were determined and were 54.40 , 54.78 and $54.85 \%$ for group I-III, respectively. Group means were not significant. In conclusion, the animals with low initial live weights had a higher fattening performance because they were in the early period of growing.
\end{abstract}

Key words: Cattle, Holstein crossbred, fattening performance, dressing percentage, Turkey

\section{INTRODUCTION}

European cattle were imported in order to increase beef and milk yield in the cattle population of Turkey. These breeds have been a great source of genetic diversity and have been used for crossbreeding throughout the world.

These cattle were raised as purebred and crossed with native breeds in Turkey too. Crossbred animals grow faster, mature at an earlier age and more efficient converter of feed to meat than native breeds (Khan, 1993). Crossbreeding is very successfully being done in developing countries to improve productivity of native stock.

Firstly purebred Holstein (30 females and 17 males) imported from the USA to Turkey in 1958 (Alpan and Aksoy, 2009). Pure and Holstein crossbred have great importance for animal production especially in seaside and Southeastern regions. Turkey's cattle population is around 11 million and $70 \%$ of them are pure improved breeds and their crossbreds with indigenous cattle.

The same data were 143000 and $53 \%$, respectively in the Sanliurfa city of Southeastern Anatolia regio. Main indigenous cattle population of the region is Southeast Anatolian Red (SAR). The SAR has ability for heat, parasite tolerance and to survive with limited food resources (Alpan and Aksoy, 2009). The southeastern Anatolia of Turkey is characterized as humid subtropical and is subject to summer periods of high ambient temperature and low relative humidity (Ekiz et al., 2005). Cattle are among the homoeothermic animals which can continue their body temperatures at a constant level in spite of the changes in the climatic conditions (Yalcin, 1981). For the fattening young bulls to continue this constant body temperature, the most suitable temperatures are in the thermo-neutrality zone of $5-25^{\circ} \mathrm{C}$.

The temperatures in this zone do not affect physiological functions negatively. However, at higher temperatures than these limits, stress effect is being observed on farm animals. These conditions cause the fall in the feed intake and decrease in the live weight gain (Akcan et al., 1991; Kocak et al., 1995; Ogan et al., 1997; Ekiz et al., 2005).

Dairy, dual-purpose breeds and their crosses are still the main source of beef in the Turkey. A major part of beef comes from Holstein, Brown swiss and their crossed breeds.

The aim of this study was to determine fattening performance and dressing percentage of Holstein crossbred bulls at different initial weight in sub-tropical climatic and intensive conditions in Sanliurfa city of Southeastern Anatolia region.

Corresponding Author: Mugdat Yerturk, Department of Animal Sciences, Faculty of Veterinary Medicine, Harran University, Sanliurfa, Turkey 


\section{MATERIALS AND METHODS}

This study was carried out in a private fattening farm in Sanliurfa city in Southeastern Anatolia region of Turkey. The animal materials of this study which were taken in fattening between January and December months were composed of Holstein crossbred young bulls. In the city, the fattening animals are generally bought 8-10 months before feast of the sacrifice and sold 1-30 days before that day. The animals which are sold must be at least 2 years old. This study was carried out to investigate fattening performance and dressing percentage of Holstein crossbred young bulls at different initial live weight in a private farm organizing its time table for feast of the sacrifice. The animals were kept in a semi roofed type of barn and managed under loose housing condition. The climate of Sanliurfa city where the study was conducted is subtropical. The monthly average environmental temperature and humidity values of the region during the dates of the study were collected by Testo electronic device in $2 \mathrm{~h}$ intervals and presented as monthly in Table 1.

There were a total of 163 pure and crossbred Holstein young bulls which were fattened in this period. For fattening, young bulls at the age of 6-16 months were bought from other farms and from the city bazaar. The young bulls in the study were divided into three groups according to their initial fattening weights (group I: 95-145 $\mathrm{kg}$, group II: $148-195 \mathrm{~kg}$ and group III: $197-265 \mathrm{~kg}$ ). Before fattening, anti-parasite medicines and vaccinations has been applied and adopted to the feed which would be used for fattening. In fattening, the feed produced in the farm containing of $13-14 \%$ crude protein, NDF $38 \% .5$, Ca $0.60 \%, \mathrm{P} 0.40 \%$ and $2500-2550 \mathrm{kcal} \mathrm{kg}^{-1}$ metabolic energy were given ad libitum with free access to water. Feed conversion rates (Roughage+Concentratefeed) which are given in tables were calculated as Dry Matter (DM). During fattening, the animals were weighted monthly by scales sensitive to $100 \mathrm{~g}$. The young bulls which had a chronic illness or under medical treatment for a long time were excluded from the study. Slaughtered and hot

\begin{tabular}{lcc}
\multicolumn{3}{c}{ Table 1: Average temperature and humidity values of the private farm } \\
\hline Months & Mean temperature $\left({ }^{\circ} \mathrm{C}\right)$ & Mean humidity (\%) \\
\hline January & 7.1 & 67.5 \\
February & 7.9 & 68.2 \\
March & 13.4 & 60.3 \\
April & 14.8 & 65.3 \\
May & 21.5 & 54.3 \\
June & 31.4 & 35.6 \\
July & 34.1 & 34.7 \\
August & 32.9 & 43.1 \\
September & 27.6 & 46.4 \\
October & 22.0 & 52.7 \\
November & 13.5 & 59.8 \\
December & 7.4 & 74.6 \\
\hline
\end{tabular}

dressing weights of 6 animals from each group which were slaughtered in the slaughter house were gathered to investigate the dressings percentage of groups. The average initial live weights of the groups were different, so the following weights of the groups were not compared. The data of average daily weight gain and fed conversions ratio were statistically analyzed by using the one way Anova technique and means were compared by Duncan's multiple-range test (Steel and Torrie, 1981).

\section{RESULTS AND DISCUSSION}

The groups had different initial weights and fed for different durations so comparisons of the live weight between groups were not eligible. Comparisons of the groups were focused to daily weight gain and fed conversions ratio.

Average initial live weight, fattening periods, final weights, average daily live weight gain, average fed conversions rate, average hot dressing percentage and their minimum and maximum data for groups have been shown in Table 2. Average daily live weight gains and fed conversions rates of the groups in the different live weights and average daily live weight gains of the whole fattening periods have been shown in Table 3. Final live weights of the groups were different due to different initial live weights.

Average daily live weight gains of the whole fattening periods of the group I-III were 1061.20 $445.6,1086.30 \pm 65.2$ and $1101.70 \pm 74.08$, respectively. Analysis of variance revealed that difference between the groups was not statistically significant $(\mathrm{p}>0.05)$ during the whole fattening periods.

Similar live weight gains in black and white bulls were also reported by (1016 g) (Alpan et al., 1976), (1076 g) (Akcan et al., 1989), (1023 g) (Ilgu and Gunes, 2002), (1110 and $1120 \mathrm{~g}$ ) (Baspinar et al., 1999), (1091 g) (Barton et al., 2003 ) and (1110 and $1120 \mathrm{~g}$ ) (Lee et al., 2009). On the other hand, higher live weight gains of black and white bulls were found (1330 g) by Ozdogan (2007) and (1336 g) Ekiz et al. (2005).

Muftuoglu et al. (1980) reported in their study that Holstein $\times$ Southeastern Anatolia red crossbred bulls which were fattened for 135 days with an initial fattening weight of 151,183 and $230 \mathrm{~kg}$, daily live weight gain of 979,1065 and $1010 \mathrm{~g}$. Baspinar (1991) determined that the Holstein $\times$ native black crossbred young bulls groups which were fattened for 292 and 340 days with the average initial fattening weights of 260 and $258 \mathrm{~kg}$ had the daily live weight gains of 865 and $873 \mathrm{~g}$, respectively. In this study, average daily live weight gains of the groups between 225-275 and 275-320 kg were found to be 
Table 2: Fattening performance and carcass percentages of the groups

\begin{tabular}{|c|c|c|c|c|c|}
\hline Property & Groups & $\mathrm{N}$ & $\mathrm{X} \pm \mathrm{Sx}$ & Min. & Max. \\
\hline \multirow[t]{3}{*}{ Average initial live weight $(\mathrm{kg})$} & I & 85 & $123.70 \pm 1.50$ & 95.000 & 145.00 \\
\hline & II & 54 & $168.56 \pm 1.82$ & 148.000 & 195.00 \\
\hline & III & 24 & $216.58 \pm 3.95$ & 197.000 & 265.00 \\
\hline \multirow[t]{3}{*}{ Fattening periods (day) } & I & 85 & $183.11 \pm 3.99$ & 116.000 & 246.00 \\
\hline & II & 54 & $176.72 \pm 5.80$ & 116.000 & 246.00 \\
\hline & III & 24 & $186.25 \pm 9.58$ & 116.000 & 246.00 \\
\hline \multirow[t]{3}{*}{ Finishing weights $(\mathrm{kg})$} & I & 85 & $319.47 \pm 4.78$ & 200.000 & 440.00 \\
\hline & II & 54 & $360.68 \pm 6.34$ & 260.000 & 470.00 \\
\hline & III & 24 & $419.04 \pm 3.89$ & 301.000 & 550.00 \\
\hline \multirow[t]{3}{*}{ Average daily live weight gain $\left(\mathrm{g} \mathrm{head}^{-1}\right)$} & I & 85 & $1061.20 \pm 45.61$ & 770.000 & 1460.00 \\
\hline & II & 54 & $1086.30 \pm 65.23$ & 860.000 & 1370.00 \\
\hline & III & 24 & $1101.70 \pm 74.08$ & 830.000 & 1480.00 \\
\hline \multirow[t]{3}{*}{ Average feed conversion rate $(\mathrm{kg})$} & I & 85 & 7.09 & 6.520 & 7.85 \\
\hline & II & 54 & 8.08 & 7.450 & 8.62 \\
\hline & III & 24 & 8.73 & 8.150 & 9.70 \\
\hline \multirow[t]{3}{*}{ Average hot dressing percentage (\%) } & I & 6 & $54.2 \pm 0.62$ & 51.420 & 56.26 \\
\hline & II & 6 & $54.5 \pm 0.57$ & 52.130 & 55.80 \\
\hline & III & 6 & $55.2 \pm 0.70$ & 52.630 & 59.30 \\
\hline
\end{tabular}

Table 3: Daily live weight gain and fed conversion rate (DM) between some live weights of groups

\begin{tabular}{|c|c|c|c|c|c|c|c|c|}
\hline \multirow[b]{2}{*}{ Live weight } & \multicolumn{3}{|c|}{ Average daily live weight gain (g) } & \multirow[b]{2}{*}{ p-value } & \multicolumn{3}{|c|}{ Average fed conversion rate $(\mathrm{kg})$} & \multirow[b]{2}{*}{ p-value } \\
\hline & Group I $(\mathrm{X} \pm \mathrm{Sx})$ & Group II (X $\pm \mathrm{Sx})$ & Group III $(\mathrm{X} \pm \mathrm{Sx})$ & & Group I $(\mathrm{X} \pm \mathrm{Sx})$ & Group II $(\mathrm{X} \pm \mathrm{Sx})$ & Group III (X $\pm \mathrm{Sx})$ & \\
\hline $125-175$ & $1152 \pm 18$ & - & - & & 6.52 & - & - & \\
\hline $175-225$ & $1118 \pm 17.5$ & $1224 \pm 20.0$ & - & & 6.89 & 7.45 & & \\
\hline $225-275$ & $1023 \pm 17.5^{\mathrm{a}}$ & $1125 \pm 23.0^{b}$ & $1275 \pm 36.6^{c}$ & $* * * *$ & 7.08 & 7.75 & 8.15 & \\
\hline $275-320$ & $951.8 \pm 17.2^{\mathrm{a}}$ & $1086 \pm 18.2^{b}$ & $1169 \pm 39.8^{b}$ & ****** & 7.85 & 8.27 & 8.45 & \\
\hline $320-360$ & - & $910 \pm 19.0$ & $1015 \pm 41.2$ & & - & 8.62 & 8.80 & \\
\hline $360-420$ & - & - & $948 \pm 38.6$ & & - & - & 9.70 & \\
\hline Average & $1061 \pm 45.6^{\mathrm{NS}}$ & $1086 \pm 65.4^{\mathrm{NS}}$ & $1101 \pm 74.2^{\mathrm{ns}}$ & NS & $7.09 \pm 29^{a}$ & $8.08 \pm 32^{\mathrm{ab}}$ & $8.73 \pm 41^{b c}$ & $*$ \\
\hline
\end{tabular}

Mean values with different letters are significantly different in the same line; ${ }^{*}=(p<0.05)$. **** $=(p<0.001)$. NS $=$ Not Significant; DM $=$ Dry Matter

significant $(\mathrm{p}<0.001)$. The average daily live weight gain differences of the fattening groups were shown in Table 3. In the study, heavier live weights animals get the more average daily live weight gain during this period. Differences of the groups in this period probably come from the genotype of the animals and from the different season. The animals in the study were grouped due to their live weights not to their age so, early grooving animals were heavier and settled to group III. Perhaps, these animals would have more daily live weights gain in the grooving period if they were fattened.

Average feed conversion ratio of the group I-III for the whole fattening periods were $7.09,8.08$ and $8.73 \mathrm{~kg}$, respectively. These data are similar to the litrature (Alpan et al., 1976; Arpacik et al., 1988) Ilgu and Gunes, 2002; Ogan et al., 1997; Gunes et al., 2001; Koc and Akman, 2003; Lee et al., 2009) findings reported before for Holsteins. However, Akcan et al. (1991) (10.5 and $9.3 \mathrm{~kg}$ ) and Tuncer and Ozbeyaz (2009) $(9.26 \mathrm{~kg})$ reported higher values for Holstein. These differences may be due to the effect of season and genotype. Average feed conversion ratio of the groups for the whole fattening periods were found statistically important $(\mathrm{p}<0.05)$. Average feed conversion ratios of the groups increase from initial to finishing period in all groups. Average feed conversion rates of the group I has been found to be lower than that of group III. This knowledge shows that the group I was nearer to the growing period.

Slaughtered weights and hot dressing percentages of 6 animals from each group at the end of fattening which slaughtered were $350.20,383.56$ and $396.20 \mathrm{~kg}$ and 54.40 , 54.78 and $54.85 \%$ for group I-III, respectively. There was no significant statistical difference between hot dressing percentages of the groups. These results were agreement with that reported by some researchers (Barton et al. 2003; Alberti et al., 2008; Sahin et al., 2009) for Holstein.

\section{CONCLUSION}

Holstein crossbred bulls in the different initial live weights which were fattened had similar average live weight gain and dressing percentage. But the animals with lower live weight had lower average feed conversion rate for the whole fattening periods.

\section{REFERENCES}

Akcan, A., R. Arpacik, G. Guneren and L. Karagenc, 1991. The effect of starting time on fattening performance in Holstein bulls. J. Lalahan Livest. Res. Inst., 31: 9-16. 
Akcan, A., T. Gurdogan and I. Cetin, 1989. Effects of different final weight of Holstein young bulls on slaughter and carcass characteristics. J. Lalahan Livest. Res. Inst., 29: 21-26.

Alberti, P., B. Panea, C. Sanudo, J.L. Olleta and G. Ripoll et al., 2008. Live weight, body size and carcass characteristics of young bulls of fifteen European breeds. Livest. Sci., 114: 19-30.

Alpan, O. and A.R. Aksoy, 2009. Cattle Breeding. Zafer Press, Erzurum, Turkey, pp: 29-36.

Alpan, O., H. Yosunkaya and K. Alic, 1976. A comparative adaptability study on imported brown, friesian and simmental cattle in Turkey. J. Lalahan Livest. Res. Inst., 16: 3-18.

Arpacik, R., A. Akcan, O. Alpan, O. Ertugrul and A.R. Aksoy, 1988. The effect of initial weight on feedlot performance, slaughter and carcass characteristics in Holstein bulls. J. Fac. Vet. Med. Univ. Ankara, 35: 124-134.

Barton, L., V. Teslik, R. Zahradkova and D. Bures, 2003. Growth, feed efficiency and carcass characteristics of Czech Pied and Holstein bulls. Czech J. Anim. Sci., 48: 459-465.

Baspinar, H., 1991. Fattening performance and carcass characteristics of holsein $\mathrm{x}$ native black crossbred young bulls in semi confinement barn condition. J. Lalahan Livest. Res. Inst., 31: 1-8.

Baspinar, H., M. Ogan and F. Balci, 1999. Fattening performance and carcass characteristics of polish holstein bulls. J. Lalahan Livest. Res. Inst., 39: 1-6.

Ekiz, B., O. Kocak, A. Yilmaz and H. Gunes, 2005. Certain fattening and slaughter characteristics of Brown Swiss young bulls in intensive conditions. J. Fac. Vet. Med. Istanbul Univ., 31: 119-128.

Gunes, H., F. Kaygisiz, O. Kocak, M. Pekgoz and M. Gor, 2001. Studies on the fattening performances of holstein friesian male cattle and economic analyses of fattening. J. Fac. Vet. Med. Univ. Istanbul, 27: 243-253.

Ilgu, E. and H. Gunes, 2002. Studies on the feedlot performance of male holstein-friesian cattle under private farm conditions. J. Fac. Vet. Med. Univ. Istanbul, 28: 313-335.
Khan, U.N., 1993. Genetic Improvement of Native Cattle Through Crossbreeding and Introduction of Exotic Dairy Cattle in Pakistan. Pakistan Science Foundation, Islamabad, Pakistan, pp: 106.

Koc, A. and N. Akman, 2003. Fattening performance and carcass characteristics of imported holstein bulls at different initial weight. J. Anim. Prod., 44: 26-36.

Kocak, D., S. Cosar and N. Tulgar, 1995. Effects of different energy levels on feedlot fattening performance and carcass characteristics of Holstein bulls, in winter. J. Lalahan Livest. Res. Inst., 35: 1-20.

Lee, W.S., M.A. Khan, H.S. Kim, J.H. Kim and S.H. Yang et al., 2009. Feed consumption, growth performance and carcass evaluation of Korean Holstein bulls fed either conventional or organic diets. Anim. Prod. Sci., 49: 306-310.

Muftuoglu, S., C. Escan and C. Toprak, 1980. Estimated of optimum slaughter age and slaughter weight of the Holstein $\mathrm{x}$ south Anatolian red bulls. J. Lalahan Livest. Res. Inst., 20: 100-112.

Ogan, M., H. Baspinar and F. Balci, 1997. The effect of starting season on fattening performance of Polish Holstein bulls. Univ. Uludag J. Fac. Vet. Med., 16: 49-55.

Ozdogan, M., 2007. A research on some sattening performance parameters of Holstein Friesian and Brown Swiss young bulls under summer season conditions in Aydýn province. J. Anim. Prod., 48: $1-6$.

Sahin, A., B. Miran, I. Yildirim, A. Onenc and A. Alcicek, 2009. Fattening costs of beef breeds reared under controlled conditions and the determination of optimum fattening period Turk. J. Vet. Anim. Sci., 33: 485-492.

Steel, R.G.D. and J.H. Torrie, 1981. Principles and Procedures of Statistics a Biometric Approach. 2nd Edn., McGraw Hill International Book Company, New york.

Tuncer, H. and C. Ozbeyaz, 2009. The effect of restricted feeding in different duration on fattening performance, slaughtering-carcas characteristics and fattening cost on Holstein cattle after puberty. J. Lalahan Livest. Res. Inst., 49: 1-15.

Yalcin, B.C., 1981. General Zootechny. Veterinary Faculty of Istanbul University, Istanbul, Turkey, pp: 145-153. 